\title{
Toxicity response of Chlorella microalgae to glyphosate herbicide exposure based on biomass, pigment contents and photosynthetic efficiency
}

\author{
Somruthai Kaeoboon ${ }^{1,2}$, Rungcharn Suksungworn ${ }^{1} \&$ Nuttha Sanevas $^{1^{*}}$ \\ ${ }^{1}$ Department of Botany, Faculty of Science, Kasetsart University, Bangkean, Bangkok 10900, Thailand \\ ${ }^{2}$ Department of Biology and Health Science, Mahidol Wittayanusorn School, Salaya, Nakhon Pathom 73160, Thailand \\ *Email: fscintsv@ku.ac.th / nuttha.s@ku.th
}

\section{ARTICLE HISTORY}

Received: 24 December 2020

Accepted: 20 February 2021

Published: 01 April 2021

KEYWORDS

Phytoplankton

Green algae

Photosynthesis

Environment

Aquatic pollution

\section{ABSTRACT}

The extensive use of glyphosate ( $\mathrm{N}$-(phosphonomethyl) glycine) herbicide in agriculture is accompanied by the risk of environmental contamination of aquatic ecosystems. In this study, the effects of glyphosate at different concentrations $\left(50-500 \mathrm{\mu g} \mathrm{m}^{-1}\right)$ on three Chlorella species including Chlorella ellipsoidea, Chlorella sorokiniana and Chlorella vulgaris especially in relation to the biomass, pigment contents and photosynthetic efficiency were assessed. After treatment for $24 \mathrm{hr}$, the acute toxicity results showed that $C$. vulgaris $\left(\mathrm{IC}_{50}=449.34 \pm 6.20 \mathrm{\mu g} \mathrm{ml}^{-1}\right)$ was more tolerant to glyphosate than C. ellipsoidea $\left(\mathrm{IC}_{50}=288.23 \pm 23.53 \mathrm{\mu g} \mathrm{ml}^{-1}\right)$ and C. sorokiniana $\left(\mathrm{IC}_{50}=174.28 \pm 0.50 \mathrm{\mu g} \mathrm{ml}^{-1}\right)$. After a $72-\mathrm{hr}$ chronic toxicity treatment with glyphosate, glyphosate concentrations decreased to $400-500 \mathrm{\mu g} \mathrm{ml}^{-1}$ in C. ellipsoidea, 200-300 $\mathrm{g} \mathrm{ml}^{-1}$ in C. sorokiniana and 200-500 $\mathrm{ug} \mathrm{ml}^{-1}$ in C. vulgaris respectively. During 24-hr acute toxicity exposure to glyphosate, the pigment contents and maximum quantum efficiency of photosystem II (Fv/Fm) decreased as the concentration of glyphosate increased. Overall, the biomass, pigment contents and photosynthetic efficiency presented a high positive correlation. It is worthwhile to mention that our study provides detailed information on the toxicity and sensitivity of these Chlorella species to glyphosate.

\section{Introduction}

Herbicides are commonly used in agricultural systems on a global scale to control weeds and to increase crop yield and quality. However, due to improper application practices and excessive use, the lack of control and unbalanced usage of herbicides largely impact environment and lead to detrimental effects on human health and ecosystems, especially in aquatic environments (1). Microalgae communities serve as an indicators help to evaluate the effects of both chemical and physical environmental parameters on ecosystems (2). In the case of microalgae, herbicides have the potential to disrupt the balance of the whole ecosystem (3-5). Specifically, herbicides have shown to seriously limit impact the biodiversity and limit the number of organisms in microalga ecological systems (6). In addition, microalgae are primary producers, base link of the aquatic food chain, and respond to environment and chemicals in aquatic ecosystems, thus their sensitivity to herbicides is critical $(7,8)$. Much research supports that microalgae might be the most promising early-alert indicator of changes in the ecological system caused by chemicals (9-11).

The Chlorella genus pertains to a small globular single-celled green algae belonging to the Chlorophyta division, is found in many aquatic systems, and is a representative of microalga in aquatic systems (12). The Chlorella species has attracted much interest for its importance in several applications, including agrochemical treatments $(13,14)$, animal feed (15-17, biofuels $(18,19)$, biological indicator $(20,21)$, food supplement (22-25) and wastewater treatment (26-28). As previously mentioned, this species, including $C$. kessleri (29), C. Protothecoides (30), C. pyrenoidosa (31), C. sorokiniana (30) and C. vulgaris (20) has also been considered a potential bio-indicator of the ecosystem, such as for chemical contamination in aquatic

(C) Kaeoboon et al (2021). This is an open-access article distributed under the terms of the Creative Commons Attribution License, which permits unrestricted use, distribution and reproduction in any medium, provided the original author and source are credited (https://creativecommons.org/licenses/by/4.0/).

To cite this article: Kaeoboon S, Suksungworn R, Sanevas N. Toxicity response of Chlorella microalgae to glyphosate herbicide exposure based on biomass, pigment contents and photosynthetic efficiency. Plant Science Today. 2021;8(2):293-300. https://doi.org/10.14719/pst.2021.8.2.1068 
environments. Notably, it is able to respond quickly to toxicity and exhibits high sensitivity towards herbicides (21).

In agricultural systems, glyphosate $(N$ (phosphonomethyl) glycine) is a commonly broadspectrum herbicide for weed control. Specifically, glyphosate interferes with 5-enol-pyruvyl-shikimate3-phosphate synthase (EPSPS), which block enzymes and prevents the production of aromatic amino acids, including phenylalanine, tyrosine and tryptophan in plants and microorganisms, through the shikimate pathway (32-34). Previous studies have been demonstrated that toxicity differences to glyphosate exposure in Chlorella microalgae, including $C$. kessleri (35, 36), C. pyrenoidosa (37-41), C. saccharophila (42), $C$. sorokiniana (43) and $C$. vulgaris $(20,42,44-49)$. While the toxicity of Chlorella microalgae can be evaluated based on their ubiquity and short life cycle (50), there are no reports on the half-maximal inhibition in response to glyphosate exposure at $24 \mathrm{hr}$ acute toxicity.

Since 1979, only 233 reports on the toxicological effects of glyphosate in aquatic environments have been published in the Web of Science database. This scarcity of research indicates the lack of knowledge on the risks of glyphosate exposure and contamination (51). More specifically, studies on the difference in sensitivity responses to the toxicity effect of glyphosate herbicide among various species and respective treatment within a short time are largely unexplored. Therefore, further research is in demand to understand herbicide toxicity and response of microalgae.

In order to assess the toxic stress of herbicides, this study examined the evolution of the toxic impact of glyphosate on the biomass, pigment contents and photosynthetic efficiency in representative of Chlorella sp. including C. ellipsoidea, C. sorokiniana and $C$. vulgaris. Therefore, the results provide knowledge on the acute and chronic toxicity of glyphosate exposure to advance our current understanding of its effects in aquatic organisms in a short time by employing unicellular Chlorella species as a further biological indicator.

\section{Materials and Methods}

\section{General chemicals and materials}

The reagents and chemicals were purchased as follows: tris base $\left(\mathrm{H}_{2} \mathrm{NC} \quad\left(\mathrm{CH}_{2} \mathrm{OH}\right)_{3}\right.$ Tris (hydroxymethyl)-aminomethan; Carlo Eraba, France), $\mathrm{NH}_{4} \mathrm{Cl}$ (FLUKA, Switzerland), $\mathrm{MgSO}_{4} \cdot 7 \mathrm{H}_{2} \mathrm{O}$ (Fisher Scientific, UK), $\mathrm{CaCl}_{2} \cdot 2 \mathrm{H}_{2} \mathrm{O}$ (Ajax Finechem, Australia), $\mathrm{K}_{2} \mathrm{HPO}_{4}$ (Ajax Finechem, Australia), $\mathrm{KH}_{2} \mathrm{PO}_{4}$ (Merck, Germany), $\mathrm{Na}_{2}$ EDTA $2 \mathrm{H}_{2} \mathrm{O}$ (Fisher Scientific, UK), $\mathrm{ZnSO}_{4} \cdot 7 \mathrm{H}_{2} \mathrm{O}$ (Ajax Finechem, Australia), $\mathrm{H}_{3} \mathrm{BO}_{3}$ (Merck, Germany), $\mathrm{MnCl}_{2} \cdot 4 \mathrm{H}_{2} \mathrm{O}$ (Carlo Eraba, France), $\mathrm{FeSO}_{4} \cdot 7 \mathrm{H}_{2} \mathrm{O}$ (Merck, Germany), $\mathrm{CoCl}_{2} \cdot 6 \mathrm{H}_{2} \mathrm{O}$ (Ajax Finechem, Australia), $\mathrm{CuSO}_{4} \cdot 5 \mathrm{H}_{2} \mathrm{O}$ (Merck, Germany), $\left(\mathrm{NH}_{4}\right) 6 \mathrm{MoO}_{3}$ (Mallinckrodt Chemical, USA), Acetic acid glacial (Carlo Eraba, France), Dimethyl sulfoxide (DMSO; Fisher Scientific, UK) and glyphosate ( $\mathrm{N}$ (Phosphonomethyl)glycine; HPLC grade, SigmaAldrich, Germany). Spectrophotometric determinations were performed using a UV-1800 UVvisible spectrophotometer (Shimadzu, Japan). The effective quantum yield was determined by pulse amplitude modulation (PAM 2500, Walz, Germany).

\section{Herbicide stock preparation}

The glyphosate used in this study was analytical grade and prepared in sterile distilled water. Serial dilution was performed to achieve the required range of concentrations from 100-500 $\mu \mathrm{g} \mathrm{ml} \mathrm{m}^{-1}$ for $C$. ellipsoidea and $C$. vulgaris and $50-300 \mu \mathrm{g} \mathrm{ml}^{-1}$ for $C$. sorokiniana. The culture medium was used as diluent.

\section{Strains and culture conditions}

C. ellipsoidea (TISTR 8260) and C. vulgaris (TISTR 8580) were purchased from the Thailand Institute of Science and Technology. C. sorokiniana strain KU.B2, which was isolated from an agricultural drainage in Nonthaburi Province, Thailand (July 2018), was obtained from the culture collection of the Department of Botany, Faculty of Science, Kasetsart University. Chlorella species was cultured in liquid TAP medium (52) containing the following micronutrients: 2.42 gm tris base, $25 \mathrm{ml}$ TAP-salt (15 gm l $\mathrm{l}^{-1} \mathrm{NH}_{4} \mathrm{Cl}, 4 \mathrm{gm} \mathrm{l}^{-1} \mathrm{MgSO}_{4} \cdot 7 \mathrm{H}_{2} \mathrm{O}$ and $2 \mathrm{gm} \mathrm{l}^{-1}$ $\left.\mathrm{CaCl}_{2} \cdot 2 \mathrm{H}_{2} \mathrm{O}\right), 1 \mathrm{ml}$ phosphate solution $\left(288 \mathrm{gm} \mathrm{l}^{-1}\right.$ $\mathrm{K}_{2} \mathrm{HPO}_{4}$ and $144 \mathrm{gm} \mathrm{l}^{-1} \mathrm{KH}_{2} \mathrm{PO}_{4}$ ), $1 \mathrm{ml}$ trace elements solution (Hutner's trace elements; $50 \mathrm{gm} \mathrm{l}^{-1}$ $\mathrm{Na}_{2}$ EDTA $\cdot 2 \mathrm{H}_{2} \mathrm{O}, 22 \mathrm{gm} \mathrm{l}^{-1} \mathrm{ZnSO}_{4} \cdot 7 \mathrm{H}_{2} \mathrm{O}, 11.4 \mathrm{gm} \mathrm{l}^{-1}$ $\mathrm{H}_{3} \mathrm{BO}_{3}, 5 \mathrm{gm} \mathrm{l}^{-1} \mathrm{MnCl}_{2} \cdot 4 \mathrm{H}_{2} \mathrm{O}, 5 \mathrm{gm} \mathrm{l}^{-1} \mathrm{FeSO}_{4} \cdot 7 \mathrm{H}_{2} \mathrm{O}, 1.6$ $\mathrm{gm} \mathrm{l}^{-1} \mathrm{CoCl}_{2} \cdot 6 \mathrm{H}_{2} \mathrm{O}, 1.6 \mathrm{gm} \mathrm{l}^{-1} \mathrm{CuSO}_{4} \cdot 5 \mathrm{H}_{2} \mathrm{O}$ and $1.1 \mathrm{gm} \mathrm{l}^{-1}$ $\left.\left(\mathrm{NH}_{4}\right) 6 \mathrm{MoO}_{3}\right)$ and $1 \mathrm{ml}$ acetic acid. Then, the medium was adjusted to $\mathrm{pH}$ 7.0. Chlorella species were cultivated at $30 \pm 1{ }^{\circ} \mathrm{C}$, under controlled conditions using white cool fluorescent light lamps (330 $\mu \mathrm{mol}$ photons $\mathrm{m}^{-2} \mathrm{~s}^{-1}$ ). The cultures were shaken five times per day during incubation. The concentration of each Chlorella mixture was quantified by cell counting with a Neubauer chamber (53). The regression equation for the relationship between cell density (y; $1.0 \times 10^{6}$ cells $\mathrm{ml}^{-1}$ ) and absorption (x; wavelength at $750 \mathrm{~nm}$ ) was calculated as follows: $\mathrm{y}=33.944 \mathrm{x}-0.8972$ $\left(\mathrm{R}^{2}=0.9998\right)$ for $C$. ellipsoidea, $\mathrm{y}=44.001 \mathrm{x}-0.7281\left(\mathrm{R}^{2}\right.$ $=0.9999)$ for $C$. sorokiniana and $\mathrm{y}=46.72 \mathrm{x}-0.3799\left(\mathrm{R}^{2}\right.$ $=1$ ) for $C$. vulgaris. The same incubation conditions were used for the determination of $\mathrm{IC}_{50}$ and in the glyphosate toxicity treatments.

\section{Toxicity experiments}

The biomass was measured as the optical density (OD) at $750 \mathrm{~nm}$, according to the standard method (54). The exponential growth phase of samples was cultured in $150 \mathrm{ml}$ culture medium in an Erlenmeyer flask with initial cell density of $1.0 \times 10^{6}$ cells $\mathrm{ml}^{-1}$ for 24, 48 and $96 \mathrm{hr}$. The biomass yield was calculated at 24, 48 and $72 \mathrm{hr}$. Inhibition of growth was monitored as an index to determine the glyphosate toxicity and the $\mathrm{IC}_{50}$ value for biomass was calculated based on $\mathrm{OD}_{750}$. In order to enable direct comparison of dose responses for $\mathrm{IC}_{50}$, all responses were converted to \% of control.

\section{Photosynthetic pigment determination}

The pigment contents were determined by spectrophotometry according to a previously 
described procedure (55). $5 \mathrm{ml}$ of each treatment was harvested then centrifuged at $3000 \mathrm{gm}$ for $15 \mathrm{~min}$. Subsequently, the supernatant was discarded and 5 ml DMSO was added to the extract of photosynthetic pigments. The samples were sonicated for $1 \mathrm{hr}$ and stored in the dark. After $24 \mathrm{hr}$, each sample was centrifuged at $3000 \mathrm{gm}$ for $15 \mathrm{~min}$. The pigments of the Chlorella microalgae samples in the supernatant were analyzed by using a spectrophotometer at appropriate wavelengths (470, 649 and $665 \mathrm{~nm})$. The resulting absorbance measurements were obtained from Wellburn (56). The equations used to calculate the pigment concentrations are as follows:

$$
\begin{aligned}
& \text { Chlorophyll } a(\mathrm{Chl} a)=12.19 \mathrm{~A}_{665}-3.45 \mathrm{~A}_{649} \\
& \text { Chlorophyll } b(\mathrm{Chl} b)=21.99 \mathrm{~A}_{649}-5.32 \mathrm{~A}_{665} \\
& \text { Total Chlorophyll }=\text { Chlorophyll } a+ \\
& \text { Chlorophyll } b \\
& \text { Total Carotenoids }=\left(1000 \mathrm{~A}_{470}-2.86 \mathrm{Chl} a-\right. \\
& 129.2 \mathrm{Chl} b) / 221
\end{aligned}
$$

The pigment contents are represented as the concentrations in $\mu \mathrm{g} \mathrm{ml} \mathrm{m}^{-1}$.

\section{Chlorophyll fluorescence}

The effect of glyphosate on chlorophyll fluorescence was measured as the effective quantum yield using a pulse amplitude modulation (PAM) fluorometer with a suspension cuvette (KS2500; diameter of $7.5 \mathrm{~mm}$, depth of $9.0 \mathrm{~mm}$ ). Monitoring of the photoinhibition in microalgae was performed using standard method (57). The effective quantum yield was determined by immersing the probe directly into the culture (measuring light intensity $=9$, gain $=4$ ) and one measurement was taken per replicate after $24 \mathrm{hr}$ treatment. The toxic response in each treatment was expressed as a percentage of control values.

\section{Statistical analysis}

The experimental treatments had three independent replicates. The results were analyzed using GraphPad Prism 6 Software (San Diego, USA). P-values lower than 0.05 were considered as statistically significant with two-way analysis of Dunnett's test. Pearson's correlation was obtained for all treatments.

\section{Results and Discussion}

\section{Growth inhibition test to assess the glyphosate toxicity}

Our study investigated the glyphosate toxicity in Chlorella microalgae, including Chlorella ellipsoidea, Chlorella sorokiniana and Chlorella vulgaris (Fig. 1) for further use as a biological indicator model. To examine the toxicity effects, C. ellipsoidea, $C$. sorokiniana and $C$. vulgaris were treated with 100-500, 50-300 and 100 to $500 \mu \mathrm{g} \mathrm{ml}$ ${ }^{1}$ glyphosate respectively. The growth inhibition test clearly manifested that glyphosate treatment induced a significant inhibitory effect on the acute toxicity in the three species after $24 \mathrm{hr}$ (Fig. 2). Compared to the control, the biomass of $C$. ellipsoidea and C. sorokiniana was significantly inhibited by $50-500 \mu \mathrm{g} \mathrm{ml}^{-1}$ glyphosate and that of C. vulgaris was inhibited at $100 \mu \mathrm{g} \mathrm{ml}^{-1}$. The

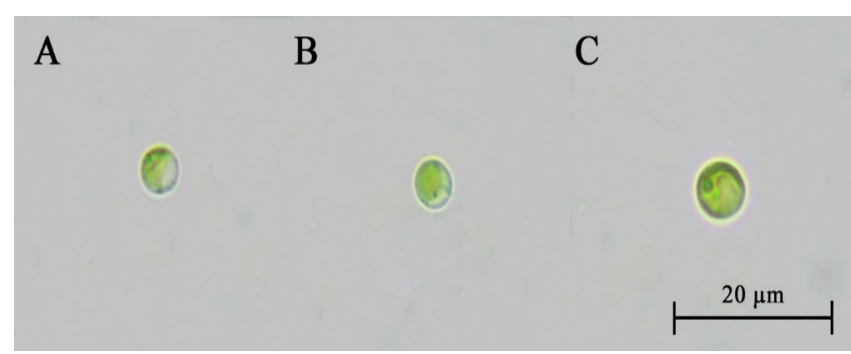

Fig. 1. Microalgae: (A) Chlorella ellipsoidea, (B) Chlorella sorokiniana and (C) Chlorella vulgaris.

growth inhibition in $C$. ellipsoidea and $C$. sorokiniana was not significantly affected by glyphosate concentrations of $300-500 \mu \mathrm{g} \mathrm{ml}^{-1}$ and 200-300 $\mu \mathrm{g} \mathrm{ml} \mathrm{g} \mathrm{m}^{-1}$ respectively. C. vulgaris $\left(\mathrm{IC}_{50}=\right.$ $449.34 \pm 6.20 \mu \mathrm{g} \mathrm{ml}{ }^{-1}$ ) showed the greatest tolerance to glyphosate compared to $C$. ellipsoidea
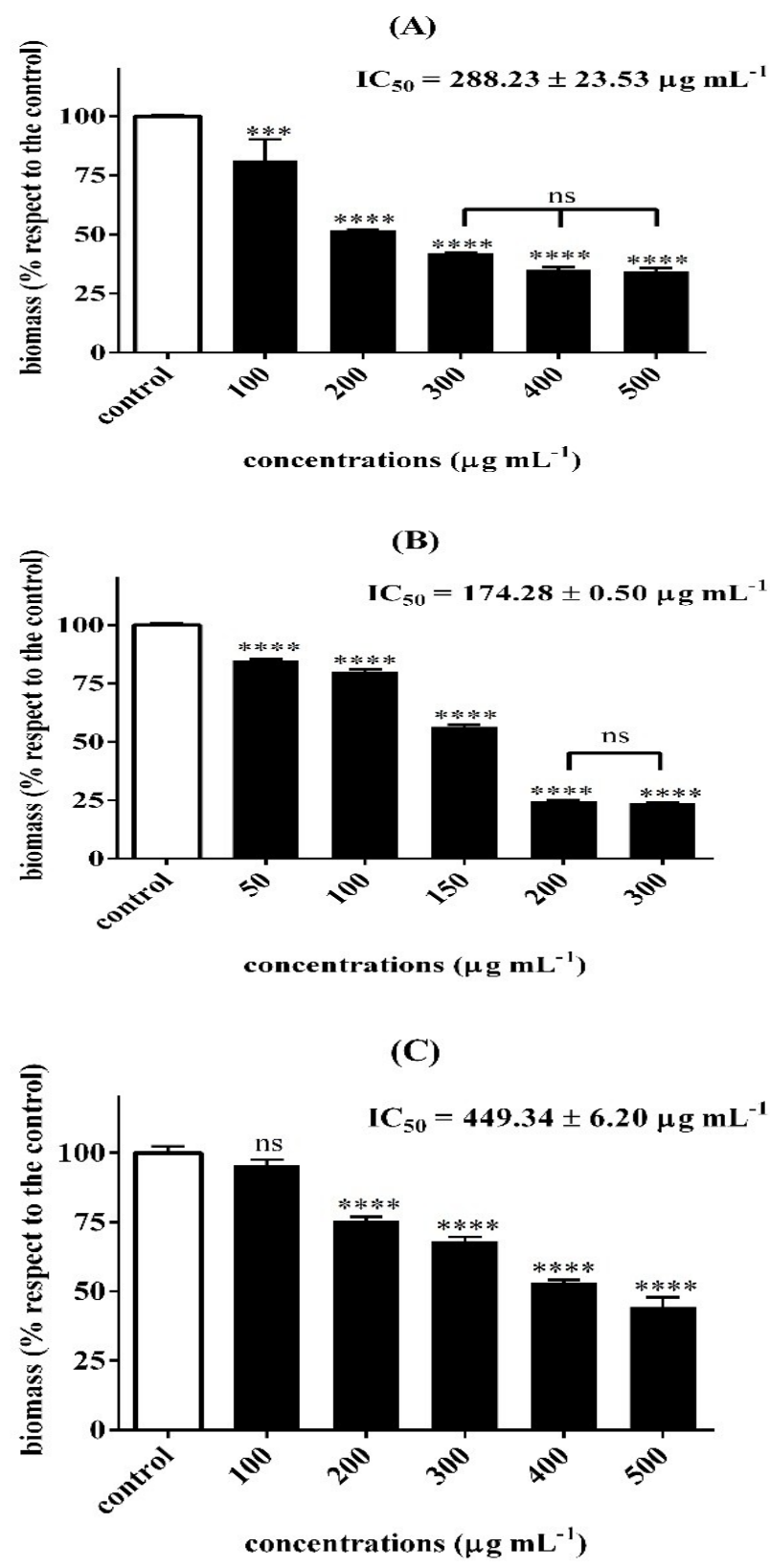

Fig. 2. Biomass of (A) Chlorella ellipsoidea, (B) Chlorella sorokiniana and (C) Chlorella vulgaris as a percentage measured from the optical density (OD) at $750 \mathrm{~nm}$ in the control (TAP) after $24 \mathrm{hr}$ exposure to $50-500 \mu \mathrm{g} \mathrm{ml}^{-1}$ glyphosate. The results are presented as the mean \pm standard deviation in triplicate $(n=3)$. 
$\left(\mathrm{IC}_{50}=288.23 \pm 23.53 \mu \mathrm{g} \mathrm{ml} \mathrm{m}^{-1}\right)$ and $C$. sorokiniana $\left(\mathrm{IC}_{50}=174.28 \pm 0.50 \mu \mathrm{g} \mathrm{m} \mathrm{m}^{-1}\right)$. As seen in Fig. 3, glyphosate caused a decrease in biomass of all species as both concentration and time increased, leading to chronic toxicity. Between 24 and $48 \mathrm{hr}$ treatment, the biomass of $C$. ellipsoidea and $C$. sorokiniana did not exceed $300 \mu \mathrm{g} \mathrm{ml}^{-1}$ and $150 \mu \mathrm{g}$ $\mathrm{ml}^{-1}$ respectively. After $72 \mathrm{hr}$ of treatment, the

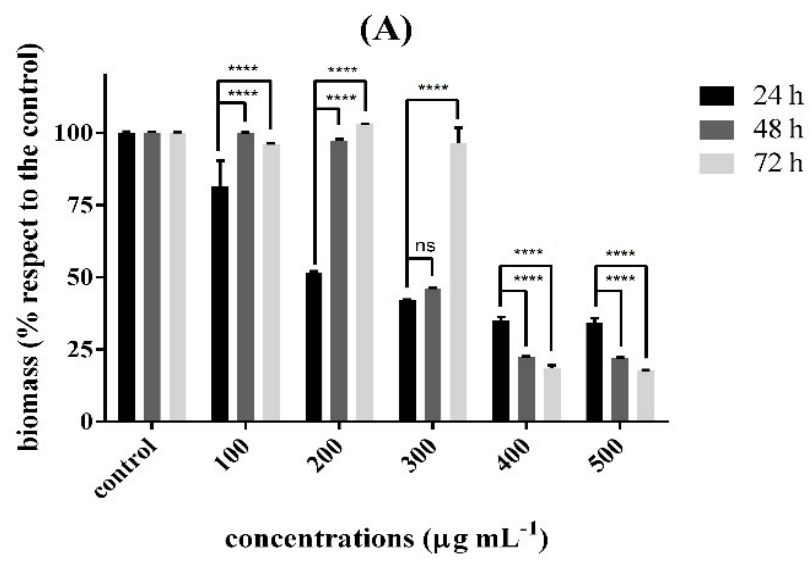

(B)
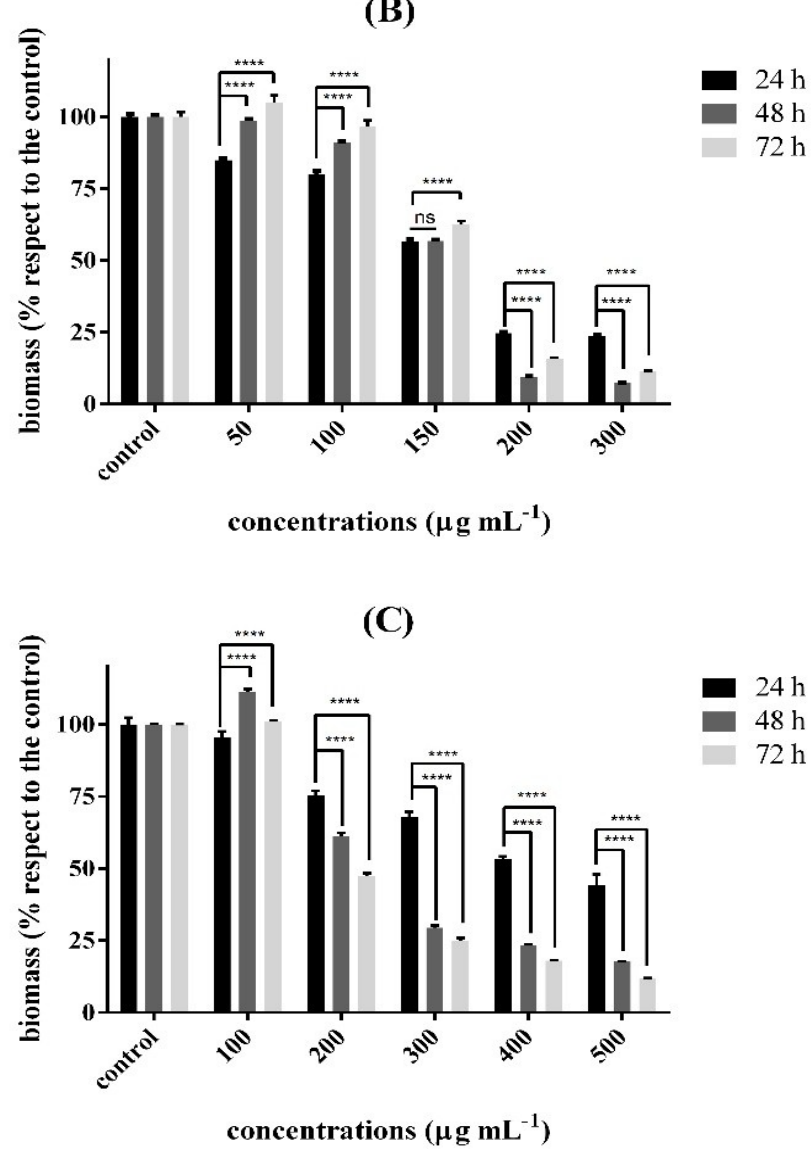

Fig. 3. Biomass of (A) Chlorella ellipsoidea, (B) Chlorella sorokiniana and (C) Chlorella vulgaris measured as the cell viability percentage at optical density (OD) of $750 \mathrm{~nm}$ in the control (TAP) after 24, 48 and $72 \mathrm{hr}$ exposure to $50-500 \mu \mathrm{g} \mathrm{ml} \mathrm{m}^{-1}$ glyphosate. The results are presented as the mean \pm standard deviation in triplicate $(n=3)$.

glyphosate concentration inhibit growth in the following order: $400-500 \mu \mathrm{g} \mathrm{ml}^{-1}$ for C. ellipsoidea, 200-300 $\mathrm{g} \mathrm{m} \mathrm{ml}^{-1}$ for $C$. sorokiniana and 200-500 $\mu \mathrm{g}$ $\mathrm{ml}^{-1}$ for $C$. vulgaris.
Many researchers have confirmed that phytoplankton appears to be the most promising early indicator of changes in aquatic system caused by chemicals $(9,10)$. Within the investigated period and database, there are no reports on $\mathrm{IC}_{50}$ that have investigated the toxicological effects of glyphosate in $24 \mathrm{hr}$. Furthermore, it was reported that $C$. sorokiniana microalgae in South African waters were the most sensitive species to glyphosate herbicide after 24 hr of exposure (30). Previous reports have demonstrated that at low glyphosate concentrations, cell growth of $C$. vulgaris increased within $24-48 \mathrm{hr}$, which is similar to our results that the cell growth of Chlorella species can recover after $24 \mathrm{hr}$. This is attributed to the phosphorus content in glyphosate, which is essential to microalgae growth (20). Several other studies also suggested that Chlorella species, including $C$. pyrenoidosa, $C$. saccharophila, $C$. sorokiniana and $C$. vulgaris are sensitive to glyphosate depending on its concentration and exposure time, which are critical parameters to determine the damage to the balance of the aquatic environment $(31,37,42,48,58)$.

\section{Pigment contents after glyphosate exposure}

After the $24 \mathrm{hr}$ treatment, the concentrations of total chlorophyll and carotenoids were significantly different among Chlorella sp. and the control. As indicated in Table 1, increased glyphosate concentration had a negative linear effect on the chlorophyll and carotenoids concentrations. Interestingly, the total carotenoid content was determined to be in the range of 300$500 \mu \mathrm{g} \mathrm{ml} \mathrm{m}^{-1}$ for C. ellipsoidea and 200-300 $\mu \mathrm{g} \mathrm{ml}^{-1}$ for $C$. sorokiniana. For both $C$. ellipsoidea and $C$. sorokiniana inhibited growth, the value of total carotenoid content was relate similar to biomass result at the same concentration.

According to a previous report, the total chlorophyll content in $C$. kessleri decreased when exposed to glyphosate in the range 84.54-338.14 $\mu \mathrm{g} \mathrm{ml} \mathrm{m}^{-1}$ within 24-96 hr (59). In another work, $C$. pyrenoidosa treated with increasing glyphosate concentrations (16.9-169.07 $\mu \mathrm{g} \mathrm{ml} \mathrm{ml}^{-1}$ ) exhibited decreased cell growth, chlorophyll and carotenoid contents (37). Compared with other green microalgae sp. chlorophyll-a content in Scenedesmus quadricauda reduced from 2-200 $\mu \mathrm{g}$ $\mathrm{ml}^{-1}$ after treated with glyphosate due to the degradation of chlorophyll biosynthesis (60-64). The toxicity of glyphosate may also affect the integrity of thylakoid membranes, preventing absorbed light energy from reaching reaction centers (65). Glyphosate may also indirectly inhibit chlorophyll synthesis by decreasing the $\mathrm{Mg}$ content (66). In fact, the $\mathrm{Mg}$ incorporation from Mg-chelatase in the porphyrin structure is an important step leading to the chlorophyll synthesis (67). It has been suggested that glyphosate may induce Fe deficiency and, thus, prevent the biosynthesis of $\delta$-aminolevulinic acid (ALA), a significant component of the chlorophyll biosynthetic pathway (68). 
Table 1. Pigment contents of chlorophyll-a (chl a), chlorophyll-b (chl b), and carotenoid in (A) Chlorella ellipsoidea, (B) Chlorella sorokiniana and (C) Chlorella vulgaris after treated with different concentrations of glyphosate $\left(50-500 \mu \mathrm{g} \mathrm{ml} \mathrm{l}^{-1}\right)$ for $24 \mathrm{hr}$. The results are presented as the mean \pm standard deviation in triplicate $(n=3)$.

(A)

\begin{tabular}{lcccccc}
\hline \multicolumn{1}{c}{$\begin{array}{c}\text { Pigment content } \\
\left(\boldsymbol{\mu g} \mathbf{~ m l}^{\mathbf{1}}\right)\end{array}$} & $\mathbf{c o n t r o l}$ & $\mathbf{1 0 0}$ & $\mathbf{2 0 0}$ & $\mathbf{3 0 0}$ & $\mathbf{4 0 0}$ & $\mathbf{5 0 0}$ \\
\cline { 2 - 7 } & $6.70 \pm 0.06$ & $4.81 \pm 0.01$ & $4.25 \pm 0.01$ & $2.06 \pm 0.02$ & $1.70 \pm 0.01$ & $1.96 \pm 0.01$ \\
\hline $\operatorname{chl} a$ & $5.50 \pm 0.04$ & $3.99 \pm 0.06$ & $3.57 \pm 0.16$ & $1.72 \pm 0.02$ & $1.26 \pm 0.02$ & $1.42 \pm 0.02$ \\
\hline $\operatorname{chl} b$ & $12.20 \pm 0.04^{\mathrm{a}}$ & $8.80 \pm 0.08^{\mathrm{b}}$ & $7.82 \pm 0.15^{\mathrm{c}}$ & $3.78 \pm 0.04^{\mathrm{d}}$ & $2.96 \pm 0.03^{\mathrm{e}}$ & $3.37 \pm .0 .21^{\mathrm{f}}$ \\
\hline total chlorophyll & $1.84 \pm 0.09^{\mathrm{a}}$ & $1.50 \pm 0.01^{\mathrm{b}}$ & $1.24 \pm 0.06^{\mathrm{c}}$ & $0.53 \pm 0.01^{\mathrm{d}}$ & $0.37 \pm 0.00^{\mathrm{d}}$ & $0.43 \pm 0.01^{\mathrm{d}}$ \\
\hline total carotenoid & & &
\end{tabular}

(B)

\begin{tabular}{|c|c|c|c|c|c|c|}
\hline \multirow{2}{*}{$\begin{array}{c}\text { Pigment content } \\
\left(\mu \mathrm{g} \mathrm{ml}^{-1}\right)\end{array}$} & \multicolumn{6}{|c|}{ Glyphosate $\left(\mu \mathrm{g} \mathrm{ml}^{-1}\right)$} \\
\hline & control & 50 & 100 & 150 & 200 & 300 \\
\hline $\operatorname{chl} a$ & $3.24 \pm 0.01$ & $2.36 \pm 0.01$ & $0.68 \pm 0.01$ & $0.44 \pm 0.01$ & $0.12 \pm 0.00$ & $0.09 \pm 0.00$ \\
\hline $\operatorname{chl} b$ & $2.83 \pm 0.01$ & $2.08 \pm 0.03$ & $0.73 \pm 0.00$ & $0.55 \pm 0.01$ & $0.22 \pm 0.01$ & $0.20 \pm 0.01$ \\
\hline total chlorophyll & $6.08 \pm 0.02^{\mathrm{a}}$ & $4.44 \pm 0.04^{\mathrm{b}}$ & $1.41 \pm 0.01^{\mathrm{c}}$ & $0.99 \pm 0.02^{\mathrm{d}}$ & $0.34 \pm 0.01^{\mathrm{e}}$ & $0.30 \pm 0.01^{\mathrm{f}}$ \\
\hline total carotenoid & $0.82 \pm 0.01^{\mathrm{a}}$ & $0.64 \pm 0.00^{\mathrm{b}}$ & $0.26 \pm 0.00^{c}$ & $0.17 \pm 0.01^{\mathrm{d}}$ & $0.10 \pm 0.00^{\mathrm{e}}$ & $0.090 \pm 0.00^{\mathrm{e}}$ \\
\hline
\end{tabular}

(C)

\begin{tabular}{lcccccc}
\hline \multicolumn{1}{c}{$\begin{array}{c}\text { Pigment content } \\
\left(\boldsymbol{\mu g} \mathbf{~ m l}^{\mathbf{1}}\right)\end{array}$} & $\mathbf{c o n t r o l}$ & $\mathbf{1 0 0}$ & $\mathbf{2 0 0}$ & $\mathbf{3 0 0}$ & $\mathbf{4 0 0}$ & $\mathbf{5 0 0}$ \\
\cline { 2 - 7 } & $5.92 \pm 0.19$ & $4.69 \pm 0.02$ & $2.80 \pm 0.01$ & $1.98 \pm 0.00$ & $1.66 \pm 0.01$ & $1.54 \pm 0.01$ \\
\hline $\operatorname{chl} a$ & $2.79 \pm 0.11$ & $3.41 \pm 0.02$ & $2.20 \pm 0.01$ & $1.71 \pm 0.01$ & $1.30 \pm 0.01$ & $1.16 \pm 0.02$ \\
\hline $\operatorname{chl} b$ & $8.71 \pm 0.09^{\mathrm{a}}$ & $8.10 \pm 0.01^{\mathrm{b}}$ & $5.00 \pm 0.02^{\mathrm{c}}$ & $3.69 \pm 0.01^{\mathrm{d}}$ & $2.96 \pm 0.02^{\mathrm{e}}$ & $2.70 \pm 0.01^{\mathrm{f}}$ \\
\hline total chlorophyll & $1.38 \pm 0.02^{\mathrm{a}}$ & $1.26 \pm 0.01^{\mathrm{a}}$ & $0.86 \pm 0.01^{\mathrm{b}}$ & $0.67 \pm 0.02^{\text {cd }}$ & $0.55 \pm 0.00^{\mathrm{d}}$ & $0.48 \pm 0.00^{\mathrm{de}}$ \\
\hline total carotenoid & & & &
\end{tabular}

\section{Photosynthetic efficiency after exposed to glyphosate}

The inhibition of effective quantum yield $\left(\mathrm{F}_{\mathrm{v}} / \mathrm{F}_{\mathrm{m}}\right)$ using pulse amplitude modulation (PAM) fluorometer revealed similar patterns in the biomass and pigment contents of the three Chlorella species after $24 \mathrm{hr}$ cumulative glyphosate exposure (Fig. 4). The results demonstrate that 400, 150 and $500 \mu \mathrm{g} \mathrm{ml}^{-1}$ glyphosate had the highest inhibition of quantum yield of $C$. ellipsoidea, C. sorokiniana and C. vulgaris, respectively. In additional, glyphosate at concentrations of 300 and $400 \mu \mathrm{g} \mathrm{ml} \mathrm{m}^{-1}$ in $C$. vulgaris presented non-significant photosynthetic effects; thus, the findings indicate that $C$. vulgaris was least influenced by glyphosate.

Glyphosate may affect photosynthesis by indirectly inhibiting the amino acids, fatty acids, carotenoids and chlorophyll biosynthesis. A previous study showed that glyphosate acts as a

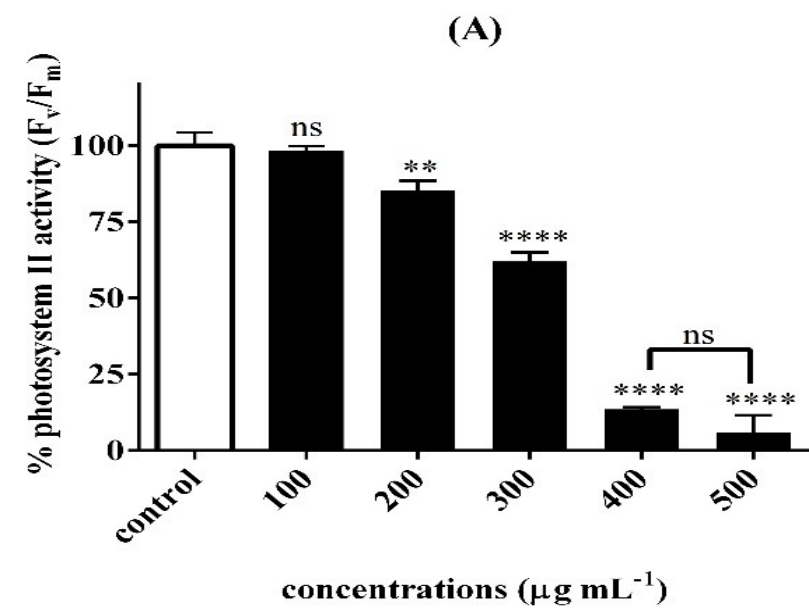

photosynthetic electron transport inhibitor, specifically inhibiting the activity of photosystem II

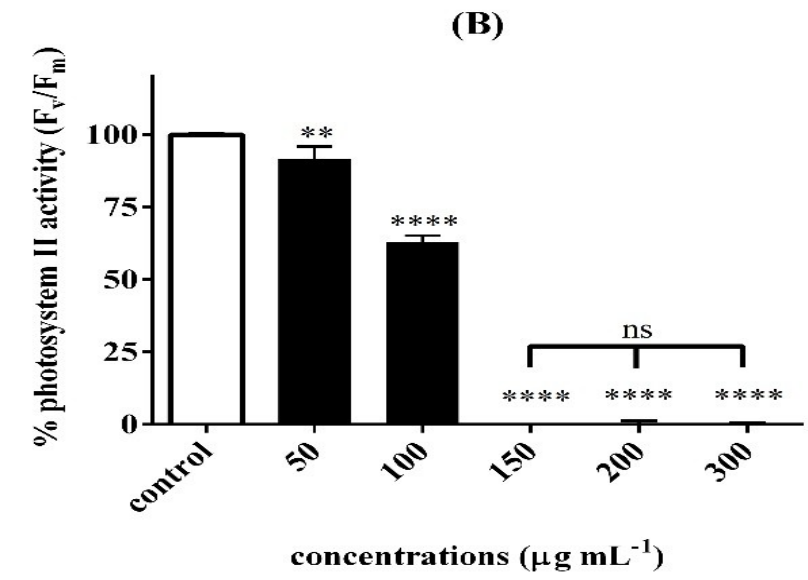

(C)

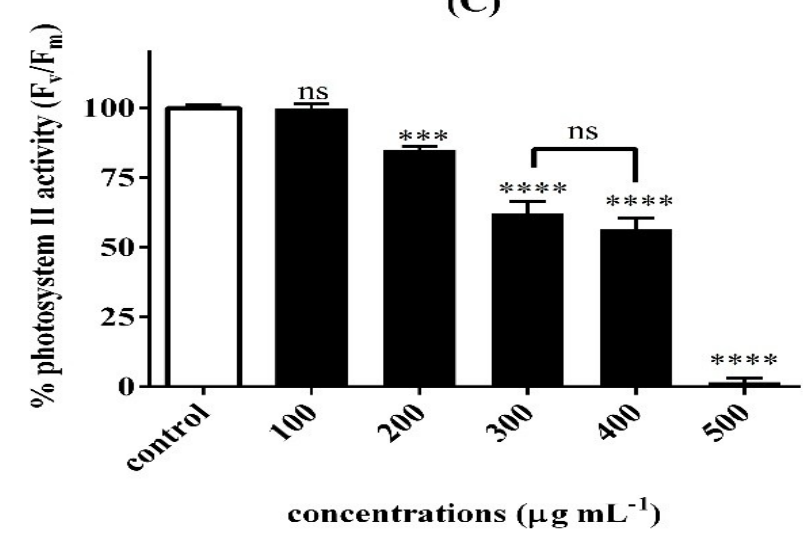

Fig. 4. The maximum quantum efficiency of photosystem II in (A) Chlorella ellipsoidea, (B) Chlorella sorokiniana and (C) Chlorella vulgaris after treated with different concentrations glyphosate $\left(50-500 \mu \mathrm{g} \mathrm{ml}^{-1}\right)$ for $24 \mathrm{hr}$. The results are presented as the mean \pm standard deviation in triplicate $(n=3)$. 
(PSII) in C. pyrenoidosa (37). Later research evaluated the effects of glyphosate on the maximum quantum efficiency of PSII using in vitro and in vivo treatments (62, 69-71). It was found that the mode of action of glyphosate inhibits the electron transport rate, PSII activity and non-photochemical energy dissipation processes. Moreover, glyphosate can alter the PSI activity (72) and decrease NADH and NADPH pools (69). In another report on the relation between biomass and photosynthesis, electron transport inhibition due to PSII inhibitors at low concentrations decreased growth rates and biomass on two tropical benthic microalgae; Navicula sp. (Heterokontophyta) and Nephroselmis pyriformis (Chlorophyta) (57).

\section{Correlation analysis}

In this study, the obtained Pearson's correlation was utilized as a guide to evaluate the correlation coefficient ( $r$ ), according to standard method (73). The correlation coefficients of the biomass, pigment contents and photosynthetic performance of three Chlorella species indicate that all species present high positive correlation $(r>0.7)$ after $24 \mathrm{hr}$ exposure. Comparing with previous study, the biomass estimates of total green algae were related to pigment contents including chlorophyll $a$ and $b$ and carotenoids (74). Especially, biomass and pigment contents including chlorophyll $a$ and $b$. Our results showed that Chlorella species growth as biomass value positive correlated with pigment contents. This results similar to previous study that the highly significant linear regressions were obtained for chlorophyll $a$, total biomass, chlorophyll b green algae and lutein-green algae (74). Moreover, the pigment indices were correlated and revealed importantly community features as biomass and diversity (75). Therefore, all results suggest that the relationship between biomass and pigment contents is directly linked to photosynthesis.

\section{Conclusion}

Our experimental results conclude that glyphosate exposure affects biomass, pigment contents and photosynthetic efficiency of Chlorella species. After 24-hr acute toxicity glyphosate exposure in terms of biomass, C. vulgaris showed the greatest tolerance, while $C$. sorokiniana was the most sensitive. After 72-hr chronic toxicity, the biomass yield of all Chlorella species was at a relatively low concentration level, further indicating that the effect of glyphosate is both concentration and timedependent. Similar to the biomass results, glyphosate exposure lead to reduced pigment contents and photosynthetic efficiency following 24-hr exposure. This indicates that the relationship between the biomass, pigment contents and photosynthetic efficiency is significantly correlated in this study. These results could be beneficial to understanding the impact and potential risk of glyphosate toxicity on microalgae in aquatic environments.

\section{Acknowledgements}

This research was partly supported by "The Mahidol Wittayanusorn School Scholarship from Mahidol Wittayanusorn School.”

\section{Authors' contributions}

NS provided conceptualization and resources, review and edited the manuscript. RS investigated experiment, review and edited the manuscript. SK investigated experiment, analyzed data and wrote the first draft of manuscript. All authors have read and approved to the published the manuscript.

\section{Conflict of interests}

The authors declare no conflict of interest.

\section{References}

1. Nwani CD, Nagpure NS, Kumar R, Kushwaha B, Kumar P, Lakra WS. Mutagenic and genotoxic assessment of atrazinebased herbicide to freshwater fish Channa puntatus (Bloch) using micronucleus test and single cell gel electrophoresis. Environ Toxicol Pharmacol. 2011;31:314-22. https://doi.org/10.1016/j.etap.2010.12.001

2. Rimet F, Cauchie HM, Hoffmann L, Ector L. Response of diatom indices to simulated water quality improvements in a river. J Appl Phycol. 2005;17:119-28. https://doi.org/10.1007/s10811005-4801-7

3. Ghosh M, Gaur JP. Current velocity and the establishment of stream algal periphyton communities. Aquat Bot. 1998;60:1-10. https://doi.org/10.1016/S0304-3770(97)00073-9

4. Stoemer EF, Smol JP. The diatoms: applications for the environmental and earth sciences. Nordic J Bot. 1999;19:384. https://doi.org/10.1002/jqs.632

5. Debenest T, Silvestre J, Coste M, Delmas F, Pinelli E. Herbicide effects on freshwater benthic diatoms: induction of nucleus alterations and silica cell wall abnormalities. Aquat Toxicol. 2008;88:88-94. https://doi.org/10.1016/j.aquatox.2008.03.011

6. Halstead NT, Mcmahon TA, Johnson SA, Raffel TR, Romansic JM, Crumrine PW, Rohr JR. Community ecology theory predicts the effects of agrochemical mixtures on aquatic biodiversity and ecosystem properties. Ecol Lett. 2014;17:932-41. https://doi.org/10.1111/ele.12295

7. Posthuma L, Suter GW, Traas TP. Environmental and ecological risk assessment: species sensitivity distributions in ecotoxicology. United States of America: Lewis publishers; 2002.

8. Oukarroum A, Bras B, Perreault F, Popovic R. Inhibitory effects of silver nanoparticles in two green algae, Chlorella vulgaris and Dunaliella tertiolecta. Ecotoxicol Environ Saf. 2012;78: 8085. http://doi.org/10.1016/j.ecoenv.2011.11.012.

9. Durrieu C, Badreddine I, Daix C. A dialysis system with phytoplankton for monitoring chemical pollution in freshwater ecosystems by alkaline phosphatase assay. J Appl Phycol.

https://doi.org/10.1023/A:1025165727616

10. Luna LM, Carmenate Z. Microalgas como biomonitores de contaminación. Revista Cubana de Química 2004;16:34-48.

11. Omar WMW. Perspectives on the use of algae as biological indicators for monitoring and protecting aquatic environments, with special reference to Malaysian freshwater. Ecosystems Trop Life Sci Res. 2010;21(2):51-67.

12. Safi C, Zebib B, Merah O, Pontalier PY, Vaca-Garcia C. Morphology, composition, production, processing and applications of Chlorella vulgaris: A review. Renewable Sustainable Energy Rev. 2014;35:265-78. https://doi.org/10.1016/j.rser.2014.04.007

13. Shaaban M. Green microalgae water extracts as foliar feeding to wheat plants. Pak J Biol Sci. 2001;4:628-32. https://doi.org/10.3923/pjbs.2001.628.632

14. Faheed F, Abd el Fattah Z. Effect of Chlorella vulgaris as biofertilizer on growth parameters and metabolic aspects of lettuce plant. J Agric Soc Sci. 2008;4:165-69. 
15. Chacón-Lee TL, González-Mariño GE. Microalgae for "Healthy” foods - possibilities and challenges. Compr Rev Food Sci Saf. 2010;9:655-75. https://doi.org/10.1111/j.1541-4337.2010.00132.x

16. Fernandes B, Dragone G, Abreu A, Geada P, Teixeira J, Vicente A. Starch determination in Chlorella vulgaris - a comparison between acid and enzymatic methods. J Appl Phycol. 2012;24:1203-08. https://doi.org/10.1007/s10811-011-9761-5

17. Gouveia L, Veloso V, Reis A, Fernandes H, Novais J, Empis J. Chlorella vulgaris used to colour egg yolk. J Sci Food Agric. 1996;70:167-72. 0010(199602)70:2<167::AID-JSFA472>3.0.CO;2-2

18. Wang K, Brown RC, Homsy S, Martinez L, Sidhu SS. Fast pyrolysis of microalgae remnants in a fluidized bed reactor for bio-oil and biochar production. Bioresour Technol. 2013;127:494-99. https://doi.org/10.1016/j.biortech.2012.08.016

19. Francisco ÉC, Neves DB, Jacob-Lopes E, Franco TT. Microalgae as feedstock for biodiesel production: carbon dioxide sequestration, lipid production and biofuel quality. J Chem Technol Biotechnol. https://doi.org/10.1002/jctb.2338

20. Reno U, Regaldo L, Vidal E, Mariani M, Zalazar C, Gagneten AM. Water polluted with glyphosate formulations: effectiveness of a decontamination process using Chlorella vulgaris growing as bioindicator. J Appl Phycol. 2016;28:227986. https://doi.org/10.1007/s10811-015-0755-6

21. Ma J, Lin F, Zhang R, Yu W, Lu N. Differential sensitivity of two green algae, Scenedesmus quadricauda and Chlorella vulgaris, to 14 pesticide adjuvants. Ecotoxicol Environ Saf. 2004;58:6167. https://doi.org/10.1016/j.ecoenv.2003.08.023

22. Grobbelaar JU. Quality Control and Assurance: crucial for the sustainability of the applied phycology industry. J Appl Phycol. 2003;15:209-15. https://doi.org/10.1023/A:1023820711706

23. Gulati OP, Ottaway PB. Legislation relating to nutraceuticals in the European Union with a particular focus on botanicalsourced products. Toxicology 2006;221:75-87. https://doi.org/10.1016/j.tox.2006.01.014

24. Rodriguez-Garcia I, Guil-Guerrero JL. Evaluation of the antioxidant activity of three microalgal species for use as dietary supplements and in the preservation of foods. Food Chem. https://doi.org/10.1016/j.foodchem.2007.11.059 2008;108:1023-26.

25. Becker EW. Micro-algae as a source of protein. Biotechnol Adv. 2007; 25:207-10. https://doi.org/10.1016/j.biotechadv.2006.11.002

26. Keffer JE, Kleinheinz GT. Use of Chlorella vulgaris for $\mathrm{CO}_{2}$ mitigation in a photobioreactor. I Ind Microbiol Biotechnol. 2002;29:275-80. https://doi.org/10.1038/sj.jim.7000313

27. de-Bashan LE, Moreno M, Hernandez JP, Bashan Y. Removal of ammonium and phosphorus ions from synthetic wastewater by the microalgae Chlorella vulgaris coimmobilized in alginate beads with the microalgae growth promoting bacterium Azospirillum brasilense. Water Res. 2002;36:2941-48. https://doi.org/10.1016/S0043-1354(01)00522-X

28. González LE, Cañizares RO, Baena S. Efficiency of ammonia and phosphorusremoval from a Colombian agroindustrial wastewater by the microalgae Chlorella vulgaris and Scenedesmus dimorphus. Bioresour Technol. 1997;60:259-62. https://doi.org/10.1016/S0960-8524(97)00029-1

29. Vries T, Duling V, Anders A. Detection of herbicides in water and their interactions with Chlorella kessleri. Environmental Sensing and Applications 1999;3821. https://doi.org/10.1117/12.364194

30. Mensah PK, Palmer CG, Muller WJ. Derivation of South African water quality guidelines for roundup using species sensitivity distribution. Ecotoxicol Environ Saf. 2013;96:24-31. https://doi.org/10.1016/j.ecoenv.2013.06.009

31. Ma J. Differential sensitivity to 30 herbicides among populations of two green algae Scenedesmus obliquus and Chlorella pyrenoidosa. Bull Environ Contam Toxicol. 2002;68:275-81. https://doi.org/10.1007/s001280249

32. Kataoka H, Ryu S, Sakiyama N, Makita M. Simple and rapid determination of the herbicides glyphosate and glufosinate in river water, soil and carrot samples by gas chromatography with flame photometric detection. J Chromatogr A 1996;726:253-58. https://doi.org/10.1016/0021-9673(95)01071-8

33. Forlani G, Mangiagalli A, Nielsen E, Suardi CM. Degradation of the phosphonate herbicide glyphosate in soil: Evidence for a possible involvement of unculturable microorganisms. Soil Biol Biochem. 1999;31:991-97. https://doi.org/10.1016/S00380717(99)00010-3

34. Gravena R, Filho RV, Alves PL, Mazzafera P, Gravena AR. Glyphosate has low toxicity to citrus plants growing in the field. Can J Plant Sci. 2012;92:119-27. https://doi.org/10.4141/cjps2011-055

35. Maršálek B, Rojíčkovâ R. Stress factors enhancing production of algal exudates: A potential self-protective mechanism?. Zeitschrift fur Naturforschung - Section C Journal of Biosciences 1996;51(9-10):646-50. https://doi.org/10.1515/znc1996-9-1008

36. Romero DM, Ríos de Molina MC, Juárez ÁB. Oxidative stress induced by a commercial glyphosate formulation in a tolerant strain of Chlorella kessleri Ecotoxicol Environ Saf 2011;74(4):741-47. https://doi.org/10.1016/j.ecoenv.2010.10.034

37. Hernando F, Royuela M, Muñoz-Rueda A, Gonzalez-Murua C. Effect of glyphosate on the greening process and photosynthetic metabolism in Chlorella pyrenoidosa. J Plant Physiol. 1989;134(1):26-31. https://doi.org/10.1016/S01761617(89)80197-X

38. Anton FA, Ariz M, Alia M. Ecotoxic effects of four herbicides (glyphosate, alachlor, chlortoluron and isoproturon) on the algae Chlorella pyrenoidosa Chick. Sci Total Environ. 1993;134 (Suppl.2):845-51. https://doi.org/10.1016/S0048-9697(05)80090-7

39. Shao Y, Jiang L, Pan J, He Y. Identification of glyphosate and butachlor by detecting Chlorella pyrenoidosa with raman microspectroscopy. Gaodeng Xuexiao Huaxue Xuebao/Chemical Journal of Chinese Universities 2015;36(6):1082-86. https://doi.org/10.7503/cjcu20140938

40. Shao Y, Li Y, Jiang L, Pan J, He Y, Dou X. Identification of pesticide varieties by detecting characteristics of Chlorella pyrenoidosa using visible/near infrared hyperspectral imaging and raman microspectroscopy technology. Water Res. 2016b;104:432-40. https://doi.org/10.1016/j.watres.2016.08.042

41. Shao Y, Jiang L, Zhou H, Pan J, He Y. Identification of pesticide varieties by testing microalgae using visible/Near infrared hyperspectral imaging technology. Sci Rep. 2016a;6:2422. https://doi.org/10.1038/srep24221

42. Vendrell E, Ferraz DGB, Sabater C, Carrasco JM. Effect of glyphosate on growth of four freshwater species of phytoplankton: A microplate bioassay. Bull Environ Contam Toxicol. 2009;82(5):538-42. https://doi.org/10.1007/s00128-009 9674-z

43. Jaiswal KK, Kumar V, Vlaskin MS, Nanda M. Impact of glyphosate herbicide stress on metabolic growth and lipid inducement in Chlorella sorokiniana UUIND6 for biodiese production. Algal Res. 2020;51: 102071. https://doi.org/10.1016/j.algal.2020.102071

44. Sáenz ME, Marzio WD. Ecotoxicity of herbicide Glyphosate to four chlorophyceaen freshwater algae. Limnetica. 2009;28(1):149-58. https://doi.org/10.1007/s00128-009-9674-z

45. Lipok J, Studnik H, Gruyaert S. The toxicity of Roundup® 360 SL formulation and its main constituents: glyphosate and isopropylamine towards non-target water photoautotrophs. $\begin{array}{llll}\text { Ecotoxicol Environ } & \text { Saf. } & \text { 2010;73(7):1681-88 }\end{array}$ https://doi.org/10.1016/j.ecoenv.2010.08.017

46. Reno U, Gutierrez MF, Regaldo L, Gagneten AM. The impact of Eskoba ${ }^{\circledR}$, a glyphosate formulation, on the freshwater plankton community. Water Environ Res. 2014;86(12):2294300. https://doi.org/10.2175/106143014x13896437493580

47. Shaker BK, Alsalman IMA, Al-Attabi MS. Effect of exposure to glyphosate pesticide, cadimum and chromium on biomass of algae (Chlorococcum humicola and Chlorella vulgaris) in polluted aqueous culture. Indian J Public Health Res Dev. 2018;9(10):708-13. 5506.2018.01219.6 https://doi.org/10.5958/0976

48. Hernández-García CI, Martínez-Jeronimo F. Multistressor negative effects on an experimental phytoplankton community. The case of glyphosate and one toxigenic 
cyanobacterium on Chlorophycean microalgae. Sci Total Environ. 2020:137186. https://doi.org/10.1016/j.scitotenv.2020.137186

49. Ostera JM, Malanga G, Puntarulo S. Assessment of oxidative balance in hydrophilic cellular environment in Chlorella vulgaris exposed to glyphosate. Chemosphere. 2020 248:125955. https://doi.org/10.1016/j.chemosphere.2020.125955

50. Rizzo L. Bioassays as a tool for evaluating advanced oxidation processes in water and wastewater treatment. Water Res. 2011;45:4311-40. https://doi.org/10.1016/j.watres.2011.05.035

51. Gonçalves BB, Giaquinto PC, Silva DS, Neto CNS, Lima AA, Darosci AAB, et al. Ecotoxicology of glyphosate-based herbicides on aquatic environment. IntechOpen. 2019. https://doi.org/10.5772/intechopen.85157

52. Andersen RA. Algal culturing techniques. $1^{\text {st }}$ ed. London: Elsevier Academic Press; 2005.

53. International Organization for Standardization (IOS). Water quality: fresh water algal growth inhibition test with Scenedesmus subspicatus and Selenastrum capricornutum. International Organization for Standardization. 1989;8692:1-6.

54. Nielsen SL, Hansen BW. Evaluation of the robustness of optical density as a tool for estimation of biomass in microalgal cultivation: The effects of growth conditions and physiological $\begin{array}{llll}\text { state. } & \text { Aquac } & \text { 2019;50(9):2698-06 }\end{array}$ https://doi.org/10.1111/are.14227

55. Martínez-Ruiz EB, Martínez-Jerónimo F. Exposure to the herbicide 2,4-D produces different toxic effects in two different phytoplankters: A green microalga (Ankistrodesmus falcatus) and a toxigenic cyanobacterium (Microcystis aeruginosa). Sci Total Environ. 2018;1:619-20:1566-78. https://doi.org/10.1016/j.scitotenv.2017.10.145

56. Wellburn AR. The spectral determination of chlorophyll a and chlorophyll b, as well as total carotenoids, using various solvents with spectrophotometers of different resolution. J Plant Physiol. 1994;144:307-13. https://doi.org/10.1016/S01761617(11)81192-2

57. Magnusson M, Heimann K, Negri AP. Comparative effects of herbicides on photosynthesis and growth of tropical estuarine microalgae. Mar Pollut Bull. 2008;56(9):1545-52. https://doi.org/10.1016/j.marpolbul.2008.05.023

58. Christy SL, Karlander E, Parochetti JV. Effects of glyphosate on the growth rate of Chlorella. Weed Sci. 1981;29(1):5-7. https://doi.org/10.1017/S0043174500025728

59. EL-Sheekh MM. Effect of glyphosate herbicide on growth, photosynthesis and some metabolic activities of the green alga Chlorella kessleri (Chlorophyta). Egypt J Phycol. 2000; 1(1):87 97. https://doi.org/10.21608/egyjs.2000.113224

60. Wong PK. Effects of 2,4-D, glyphosate and paraquat on growth, photosynthesis and chlorophyll-a synthesis of Scenedesmus quadricauda Berb 614. Chemosphere. 2000;41(1-2):177-82. https://doi.org/10.1016/s0045-6535(99)00408-7

61. Reddy KN, Rimando AM, Duke SO. Aminomethylphosphonic acid, a metabolite of glyphosate, causes injury in glyphosate reated, glyphosate-resistant soybean. J Agric Food Chem. 2004;52:5139-43. https://doi.org/10.1021/jf049605v

62. Mateos-Naranjo E, Redondo-Gómez S, Cox L, Cornejo J, Figueroa ME. Effectiveness of glyphosate and imazamox on the control of the invasive cordgrass Spartina densiflora. Ecotoxicol Environ Saf. 2009;72:1694-700. https://doi.org/10.1016/j.ecoenv.2009.06.003
63. Zobiole LHS, Kremer RJ, Oliveira RS, Jr. Constantin J, Oliveira RS. Glyphosate affects chlorophyll, nodulation and nutrient accumulation of "second generation" glyphosate-resistant soybean (Glycine max L.). Pestic Biochem Physiol. 2011b;99:5360. https://doi.org/10.1016/j.pestbp.2010.10.005

64. Huang J, Silva EN, Shen Z, Jiang B, Lu H. Effects of glyphosate on photosynthesis, chlorophyll fluorescence and physicochemical properties of cogongrass (Imperata cylindrica L.). Plant Omics Journal 2012;5:177-83.

65. Gomes MP, Le Manac'h SG, Hénault-Ethier L, Labrecque M, Lucotte M, Juneau P. Glyphosate-dependent inhibition of photosynthesis in willow. Front. Plant Sci. 2017;8:1-13. https://doi.org/10.3389/fpls.2017.00207

66. Cakmak I, Yazici A, Tutus Y, Ozturk L. Glyphosate reduced seed and leaf concentrations of calcium, manganese, magnesium and iron in non-glyphosate resistant soybean. Eur J Agron. 2009;31:114-19. https://doi.org/10.1016/j.eja.2009.07.001

67. Tanaka R, Tanaka A. Tetrapyrrole biosynthesis in higher plants. Annu Rev Plant Biol. 2007;58:321-46. https://doi.org/10.1146/annurev.arplant.57.032905.105448

68. Marsh HVJ, Evans HJ, Matrone G. Investigations of the role of iron in chlorophyll metabolism II. Effect of iron deficiency on chlorophyll synthesis. Plant Physiol. 1963;38:638-42. https://doi.org/10.1104/pp.38.6.638

69. Vivancos PD, Driscoll SP, Bulman CA, Ying L, Emami K, Treumann A, et al. Perturbations of amino acid metabolism associated with glyphosate-dependent inhibition of shikimic acid metabolism affect cellular redox homeostasis and alter the abundance of proteins involved in photosynthesis and photorespiration. Plant Physiol. 2011;157:256-68. https://doi.org/10.1104/pp.111.181024

70. Yanniccari M, Tambussi E, Istilart C, Castro AM. Glyphosate effects on gas exchange and chlorophyll fluorescence responses of two Lolium perenne L. biotypes with differential herbicide sensitivity. Plant Physiol Biochem. 2012;57:210-17. https://doi.org/10.1016/j.plaphy.2012.05.027

71. Choi CJ, Berges JA, Young EB. Rapid effects of diverse toxic water pollutants on chlorophyll a fluorescence: variable responses among freshwater microalgae. Water Res. 2012;46:2615-26. https://doi.org/10.1016/j.watres.2012.02.027

72. Muñoz-Rueda A, Gonzalez-Murua C, Becerril JM, Sánchez-Díaz MF. Effects of glyphosate [ $N$-(phosphonomethyl)glycine] on photosynthetic pigments, stomatal response and photosynthetic electron transport in Medicago sativa and Trifolium pratense. Physiol Plant. 1986;66:63-68. https://doi.org/10.1111/j.1399-3054.1986.tb01234.x

73. Mukaka MM. Statistics corner: A guide to appropriate use of correlation coefficient in medical research. Malawi Medica Journal: the Journal of Medical Association of Malawi. 2012;24(3):69-71.

74. Descy JP, Métens A. Biomass-pigment relationships in potamoplankton. J Plankton Res. 1996;18(9):1557-66. https://doi.org/10.1093/plankt/18.9.1557

75. Borghini F, Colacevich A, Caruso T, Bargagli R. Algal biomass and pigments along a latitudinal gradient in Victoria Land lakes, East Antarctica. Polar Research. 2016;35. https://doi.org/ 10.3402/polar.v35.20703 